\title{
Scrum Method Implementation in a Software Development Project Management
}

\author{
Putu Adi Guna Permana \\ STMIK STIKOM BALI \\ Denpasar, Bali
}

\begin{abstract}
To maximize the performance, companies conduct a variety of ways to increase the business profit. The work management between one company and the other company is different, so the differences in the management may cause the software to have a different business process. Software development can be defined as creating a new software or fixing the existing one. Technology developments led to increasing demand for software, Industrial Technology (IT) Companies should be able to project well maintenance. The methodology in software development is used in accordance with the company's needs based on the SDLC (Software Development Life Cycle). Scrum method is a part of the Agile method that is expected to increase the speed and flexibility in software development project management.
\end{abstract}

Keywords-Metode Scrum; Agile; SDLC; Software

\section{INTRODUCTION}

Companies in effort to maximize its performance will try a variety of ways to increase the business profit [6]. Information technology can help the company to make a better decision, faster responses to the business, increase the communication, and make a smart investment [14]. The business development impacts on the increasing needs of software which is appropriate with the demands [4]. The needs to manage the works of one company is different between one and another, therefore the software used will be different [5]. The differences factor of the software makes the information technology companies compete in the software development business. Changes in business is a common thing in the world of business, by those changes, it may also increase the projects for software developments [1]. Software development can be defined as a process to make a new software to replace the old software or to fix the existing software [2]. To describe the solution and to develop the software faster and more precise, and to make the result to be easily developed and maintained, the development of the software needs a specific methodology [16]. Software development methodology is a process of organizing a set of method and notation convention which has been defined to develop software [8]. SDLC is a software development life cycle that consists of several key stages in building software in terms of its development. With SDLC cycle, the process of building the system is divided into several steps and on large systems, each step is done by different teams [9]. SDLC is not only important for the software production process, but also very important for the software maintenance process. Agile method is one of several methods used in software development. Agile method is a type of short-term system development that requires rapid adaptation in any form of changes [15]. In Agile Software Development, the interactions and personnel is more important than the process and the tools, a working software is more important than a complete documentation, collaboration with the clients is more important than the contract negotiation, and being responsive to changes is more important than following the plan [10]. The Scrum framework is a part of the Agile Methodology which is expected to increase the speed and flexibility in the software development project.

\section{LITERATURE REVIEW}

\section{A. Agile}

Agile Software development is one of the methodologies in the development of a software. The word Agile means to be fast, lightweight, free-moving, alert. Agile is a word used to describe a process model concept which is different from the existing process model concepts [10]. Agile software development concepts coined by Kent Beck and his 16 colleagues by stating that the Agile Software Development is a way to build software by doing it and helping others to build it all at once [3]. In Agile Software Development the interactions and personnel is more important than the process and the tools, a working software is more important than a complete documentation, collaboration with the clients is more important than the contract negotiation, and being responsive to changes is more important than following the plan. However, just as other process models, Agile Software Development has its own advantages and is not suitable for all types of projects, products, people and situations. Agile Software Development enables process model which is tolerant of the requirement changes so the response to the changes can be done faster.

\section{B. SDLC (Software Development Life Cycle)}

SDLC is the stages of work performed by system analysts and programmers in building an information system. The stages are as follows:

- Conduct a survey and assess the feasibility of information systems development project

- Study and analyze the information systems that are running

- Determine the requests of the information system users

- Select the best solution or problem solving

- Determine the hardware and software.

- Design a new information system 
- Build a new information system

- Communicate and implement the new information system

- Maintain and repair / improve the new information system if necessary

System Development Life Cycle (SDLC) is a whole process in building a system through several steps [9]. There are several models of the SDLC, the model which is quite popular and widely used is the waterfall. Some other models of SDLC for example are fountain, spiral, rapid, prototyping, incremental, build and fix, and synchronize and Stabilize. With SDLC cycle, the process of building the system is divided into several steps and on large systems, each step is done by different teams.

\section{Software}

Software is a computer program that serves as a means of interaction between the user and the hardware. The software can also be regarded as a "translator" of commands that is run by the computer users to be forwarded or processed by the hardware [12].

\section{Scrum}

Scrum was developed by Jeff Sutherland in 1993 and its goal is to become a development and management methodology that follows the principles of Agile methodology [13]. Scrum is an additional responsive framework of software development for software projects and manage products or application development. The focus is on "strategy, a flexible holistic product development where the development team worked as a unit to achieve common goals" as opposed to "traditional approaches, a sequence" [5]. Scrum has a complex process in which many factors that affect the final result.

\section{E. Role Scrum}

In the Role Scrum, it is divided into 3 parts: Product Owner, Scrum Master and Team [17]. Product Owner is the person responsible for determining the specifications or the business of software applications to be built. Product Owner will register all the initial requirements to be done by the Team (known as the Product Backlog). Team is the one who runs the project, such as business analysts, system analysts, developers, testers and others. Team is the one who will be responsible for completing the Product Backlog provided by the Product Owner, Where the members of the team are responsible for each Backlog which has been divided as well as capable for knowing what to do next. Scrum Master is the one who set the scrum process during the project. Scrum Master will introduce and implement how Scrum works to the team and make sure everyone on the project implementing Scrum method.

\section{F. Scrum Flow}

A project with Scrum method begins with a depiction of the system that will be done. Then the Project Owner depicts the business process or plan into a Product Backlog [13]. Product Backlog is a list of plans that must be done by the team. There is a term in Scrum called the Sprint. Sprint is the goal to be achieved in the next scrum sprint (30 days ahead). Each Sprint starts with a Sprint Meeting Planing which is an activities to determine what kind of sprint to do next. Every day, each team gather together and discuss "What has been done since the last Daily Scrum Meeting?", "What problems are encountered during the work?", And "What will be done for the next scrum?"[5]. The meeting will be chaired by the Scrum Master and at the end of the sprint there will be a meeting for 4 hours to do a demo against everything that has been done.

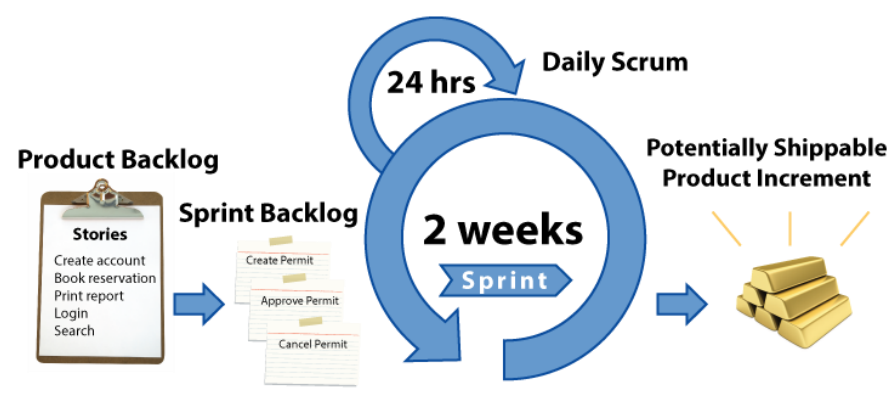

Fig. 1. Flow Scrum

\section{Methodology}

The research steps starts from the Development Preparation, maximize the writer/researcher study of literature for a deeper comprehension of the Scrum Method on a project. Besides the study of literature, author will also do consultations with the people who have been involved directly in Scrum to find information related to the challenges and obstacles during the process. The study also gives the knowledge about the Scrum framework and its implementation on the software development project management and manage scrum project using red mine application.

\section{DISCUSSION AND RESULT}

\section{A. Discussion}

Writer implements the Scrum methodology on software development project using 6 personnel. The stages used will be explained in the next section.

\section{Case Study In Arium Core Project Finance SMI:}

In the process the project will be done by six personnel with the following tasks:

- Project Manager who is in charge to monitor, control, and responsible for the overall project

- Business Analyst who is in charge of analyzing the business to be developed

- Systems Analyst who is in charge to conduct a feasibility study, analysis and design to meet the requirements of users and applications

- Programmers 1 who is in charge of the design process, perform coding and internal testing of the program to support the application system

- Programmer 2 is in charge to assist Programmer 1

- Tester in charge of checking the program that is produced by the Programmer whether it has meet the requirements or not. 
Scrum Team consists of three parts, they are:

- Product Owner (PO) consists of Project Manager and Business Analyst.

- Scrum Master (SM) consists of a Systems Analyst.

- The team consists of Programmer and Tester.

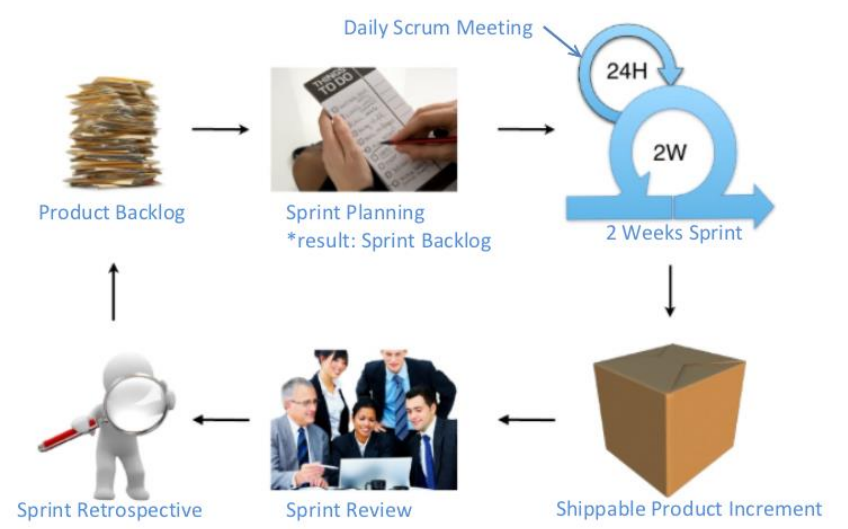

Fig. 2. Process Scrum

After the division of the scrum team on the Scrum process will be carried out as follows:

\section{1) Determine The Product Backlog}

Product Owner prepares the backlogs that will be the product backlog. The first step of Scrum is the determination of features based on priorities by the Scrum Master. In the case of determining the Product Backlog, the Scrum Master role is held by the Project Manager. A list of features that will be built according to priorities can be seen in Table 1 .

So total there are three features that will be developed on Arium Core Project Finance SMI. The list of features is then called the Product Backlog.

\section{2) Sprint Planning}

All of the scrum team conducts a meeting to make the agenda of what will be done. After determining the Product Backlog meeting held at the beginning of each Sprint to evaluate the Product Backlog, discuss the purpose and mission of each feature as desired by the Product Owner. On the Sprint Planning part the team members will determine how many hours each member will spend to carry out work on each feature. The people who choose that backlog should explain why choosing that tasks and understand what will be done. Details can be seen in Table 2.

Time for the first Sprint is determined to be 2 weeks and because the team only consisted of six people, and features that are done is still a UI (Display). After the working hours are determined, the team can start working on the first feature in the Product Backlog. The Product Backlog feature worked together in accordance with their respective roles in the team.
All changes that occur during development should be postponed until the next Sprint.

\section{3) Dialy Stand Up Meeting}

As a practice to monitor the performance, there should be a meeting every day for reporting what has each member of the team done. At this stage of the Daily Stand Up Meeting not all of the team members must be present, but rather the members involved specifically on the features that are being developed (Team). At the end of each meeting, the time of completion renewed to know the rest of the work that is need to be pursued during the running Sprint. For examples of the implementation of the first to feature Sprint input commodity prices can be seen in Table 3.

TABLE I. Features List Software DeVelopment Project Arium CORE FINANCE SMI

\begin{tabular}{|l|l|l|}
\hline No & Backlog Item & Description \\
\hline 1 & Partial Prepayment & $\begin{array}{l}\text { Partial Prepayment Module is used to make } \\
\text { early repayment of some of the Outstanding } \\
\text { Principal debtor }\end{array}$ \\
\hline 2 & Top Up And Renewal & $\begin{array}{l}\text { Top Up And Renewal module is a module } \\
\text { that is used for recording on tenor extension } \\
\text { process, the addition of ceiling, changes in } \\
\text { interest rates on a facility that has been } \\
\text { active }\end{array}$ \\
\hline 3 & Early Termination & $\begin{array}{l}\text { Early Termination Module is used to make } \\
\text { early payment for all liabilities of the } \\
\text { debtor, which includes principal, interest, } \\
\text { late penalties and other obligations of the } \\
\text { debtor }\end{array}$ \\
\hline
\end{tabular}

TABLE II. Working TIME PLAN

\begin{tabular}{|c|c|}
\hline Weeks Sprint & Total Days \\
\hline 2Week & 10Days \\
\hline
\end{tabular}

\begin{tabular}{|c|c|c|c|}
\hline Role in team & Days & $\begin{array}{c}\text { Hours / } \\
\text { Days }\end{array}$ & $\begin{array}{c}\text { Total Hours } \\
\text { Sprint }\end{array}$ \\
\hline Project Manager & 4 & 4 & 16 \\
\hline Bussiness Analyst & 8 & 4 & 32 \\
\hline $\begin{array}{c}\text { System Analyst } \\
\text { (ScrumMaster) }\end{array}$ & 8 & 4 & 32 \\
\hline Programmer1 & 10 & 5 & 50 \\
\hline Programmer2 & 10 & 5 & 50 \\
\hline Tester & 6 & 4 & 24 \\
\hline
\end{tabular}




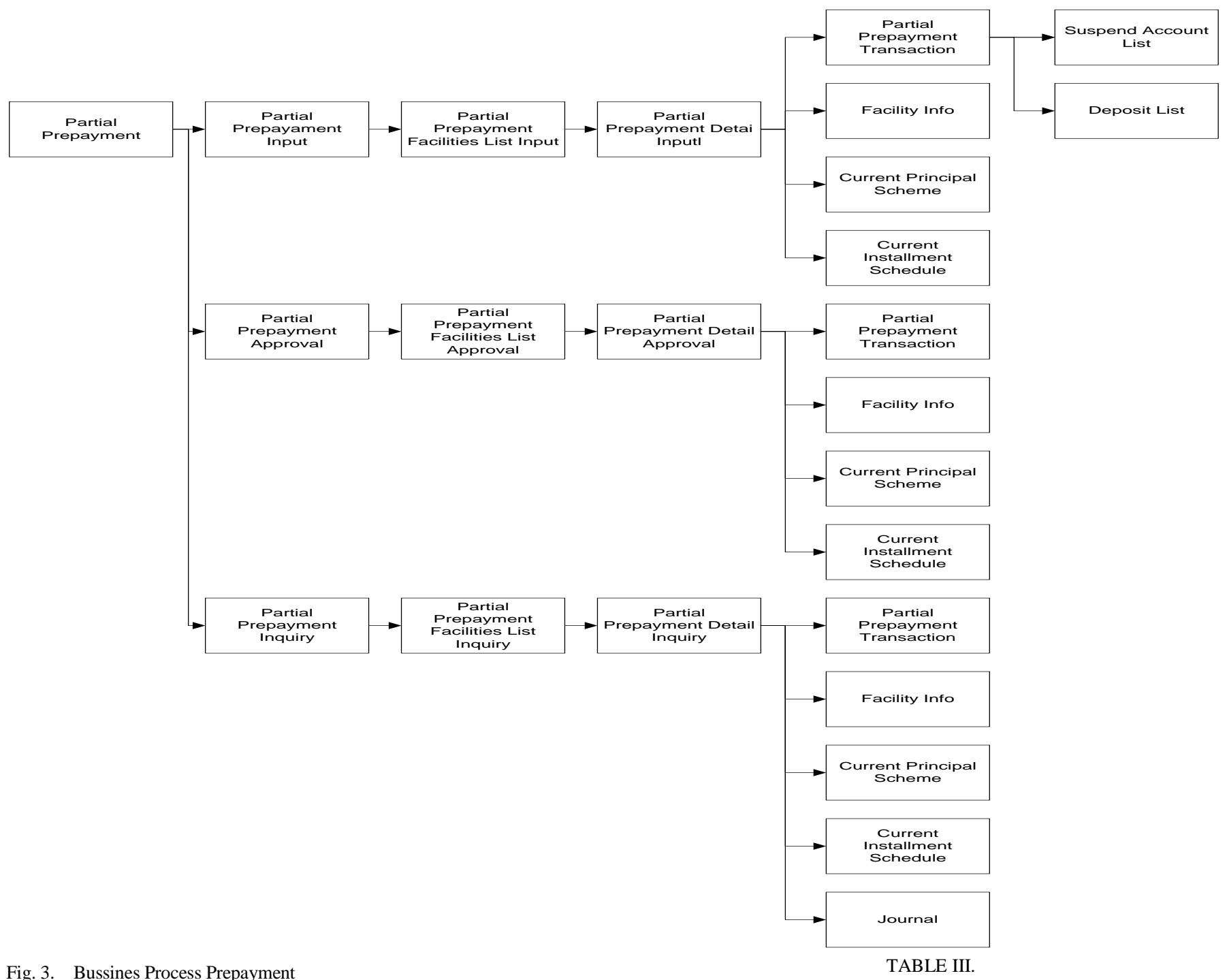

Fig. 3. Bussines Process Prepayment

TABLE IV. SPRINT BACKLOG FITURE

\begin{tabular}{|c|c|c|c|c|c|c|c|c|c|c|c|c|c|}
\hline \multirow[b]{2}{*}{ Fiture Backlog } & \multirow[b]{2}{*}{ Task } & \multirow[b]{2}{*}{ AT } & \multirow[b]{2}{*}{$\begin{array}{l}\mathbf{E} \\
\mathbf{T}\end{array}$} & \multicolumn{10}{|c|}{ The number of remaining hours / day Sprint } \\
\hline & & & & H 1 & $\mathrm{H} 2$ & H3 & H4 & H5 & H6 & $H 7$ & H8 & H9 & H10 \\
\hline \multirow{7}{*}{$\begin{array}{c}\text { Partial } \\
\text { Prepayment }\end{array}$} & $\begin{array}{l}\text { Business } \\
\text { Process } \\
\text { Design }\end{array}$ & $\begin{array}{l}\text { Bussines } \\
\text { Analyst }\end{array}$ & 5 & 3 & 0 & 0 & 0 & 0 & 0 & 0 & 0 & 0 & 0 \\
\hline & $\begin{array}{l}\text { Interface } \\
\text { Design }\end{array}$ & $\begin{array}{l}\text { System } \\
\text { Analyst }\end{array}$ & 5 & 5 & 4 & 2 & 0 & 0 & 0 & 0 & 0 & 0 & 0 \\
\hline & $\begin{array}{l}\text { Database } \\
\text { Design }\end{array}$ & $\begin{array}{l}\text { System } \\
\text { Analyst }\end{array}$ & 5 & 5 & 5 & 5 & 3 & 0 & 0 & 0 & 0 & 0 & 0 \\
\hline & $\begin{array}{l}\text { Coding } \\
\text { Front End }\end{array}$ & $\begin{array}{l}\text { Programme } \\
\text { r } 1\end{array}$ & 20 & 20 & 18 & 16 & 14 & 10 & 6 & 3 & 0 & 0 & 0 \\
\hline & $\begin{array}{l}\text { Coding } \\
\text { Back End }\end{array}$ & $\begin{array}{l}\text { Programme } \\
\text { r } 2\end{array}$ & 20 & 20 & 20 & 18 & 14 & 12 & 8 & 4 & 0 & 0 & 0 \\
\hline & \multirow[t]{2}{*}{ Testing } & $\begin{array}{l}\text { ProjectMa } \\
\text { nager }\end{array}$ & 2 & 2 & 2 & 2 & 2 & 2 & 2 & 0 & 0 & 0 & 0 \\
\hline & & Tester & 4 & 4 & 4 & 4 & 4 & 3 & 0 & 0 & 0 & 0 & 0 \\
\hline
\end{tabular}

Notes:

$\mathbf{E T}=$ Estimated Time 
As it can be seen in Table 3, the software development project starts with the first feature and system design. The system design itself is done by business analysts and system analysts covering the business processes, interfaces, and database. Once the design is completed then the task of programmers is to do the coding until it can be tested by the testers and the project managers. The process also applies for the other features in the backlog, and if it's not completed then Sprint will be continued until the products meet user needs.

Fig 4 and Fig 5 is the picture of the work process that is going on in the scrum, the real updated work based on each team tasks. In the process of work there is a story, criteria, planned, in progress, done and bugs. Story is used as columns to add cases that required by module that is worked on. Criteria is the kind of task to be done such as a partial prepayment module input. Planned is a work plan done in order to complete the task on criteria. Work still in progress will be put in in progress column, which has been completed will be entered into the column done, and if there are still business errors or mistakes in the module will be put into the bugs column.

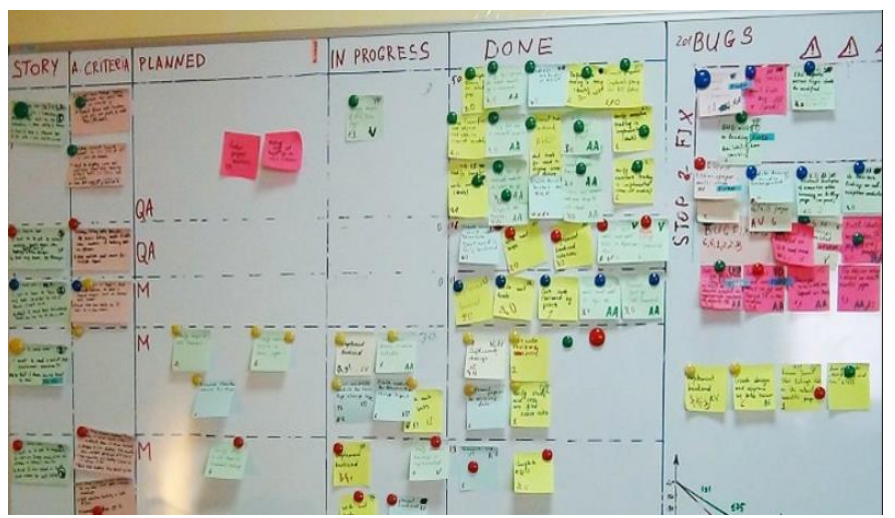

Fig. 4. Monitoring (Manual Board)

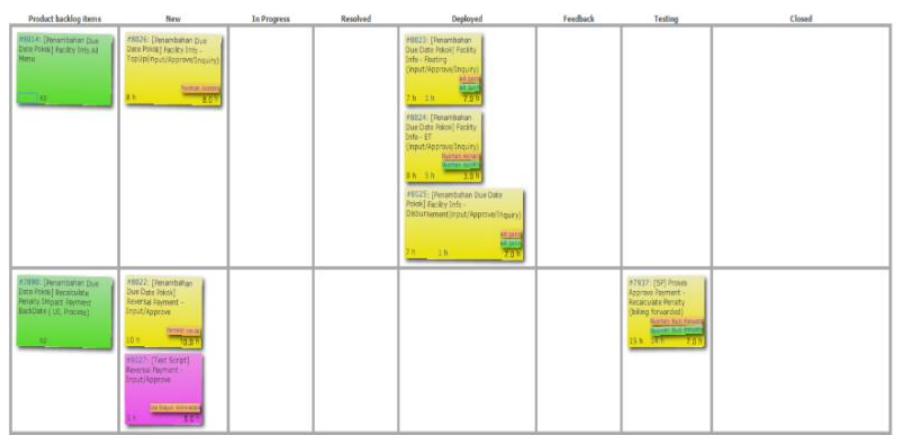

Fig. 5. Monitoring (Online Sprint Board)

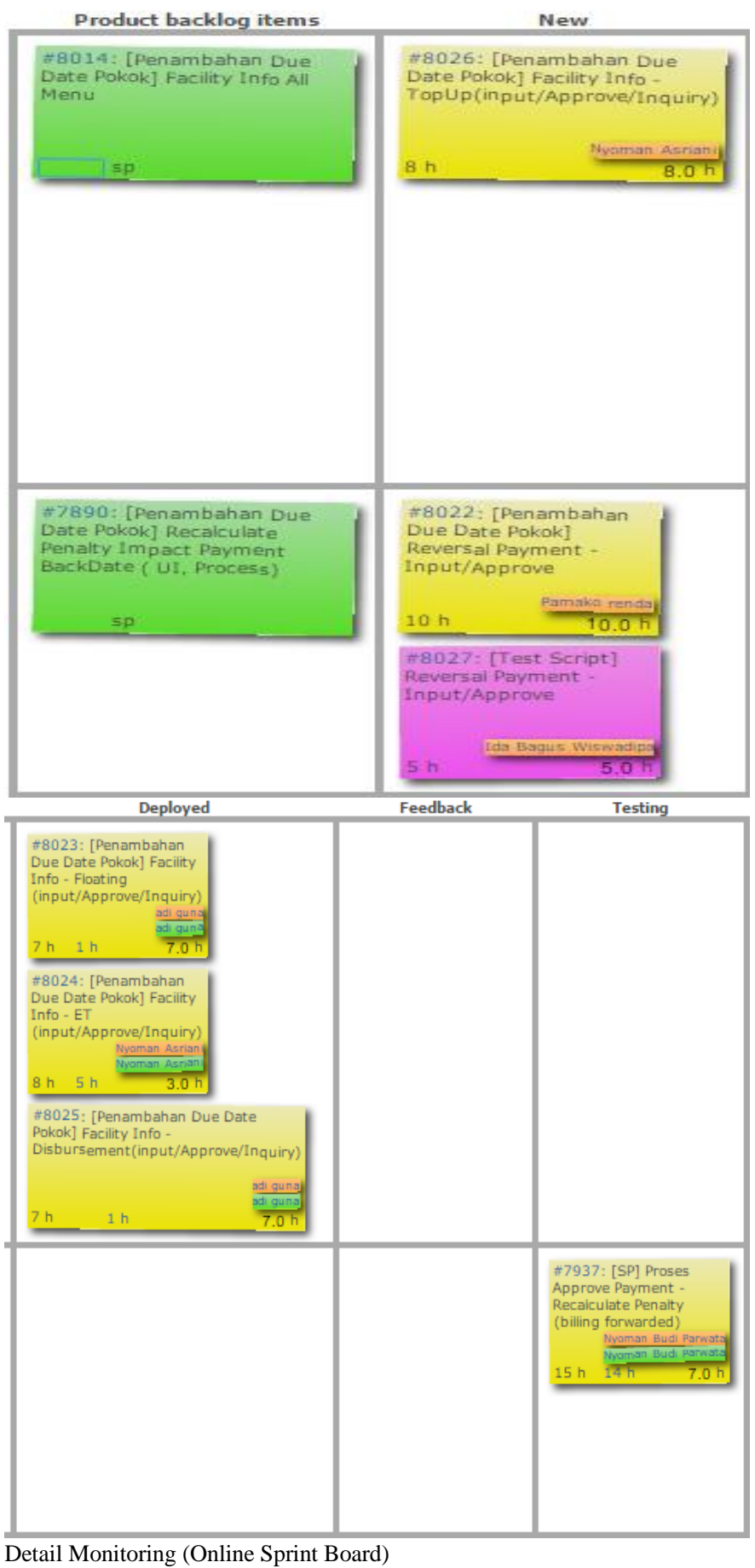




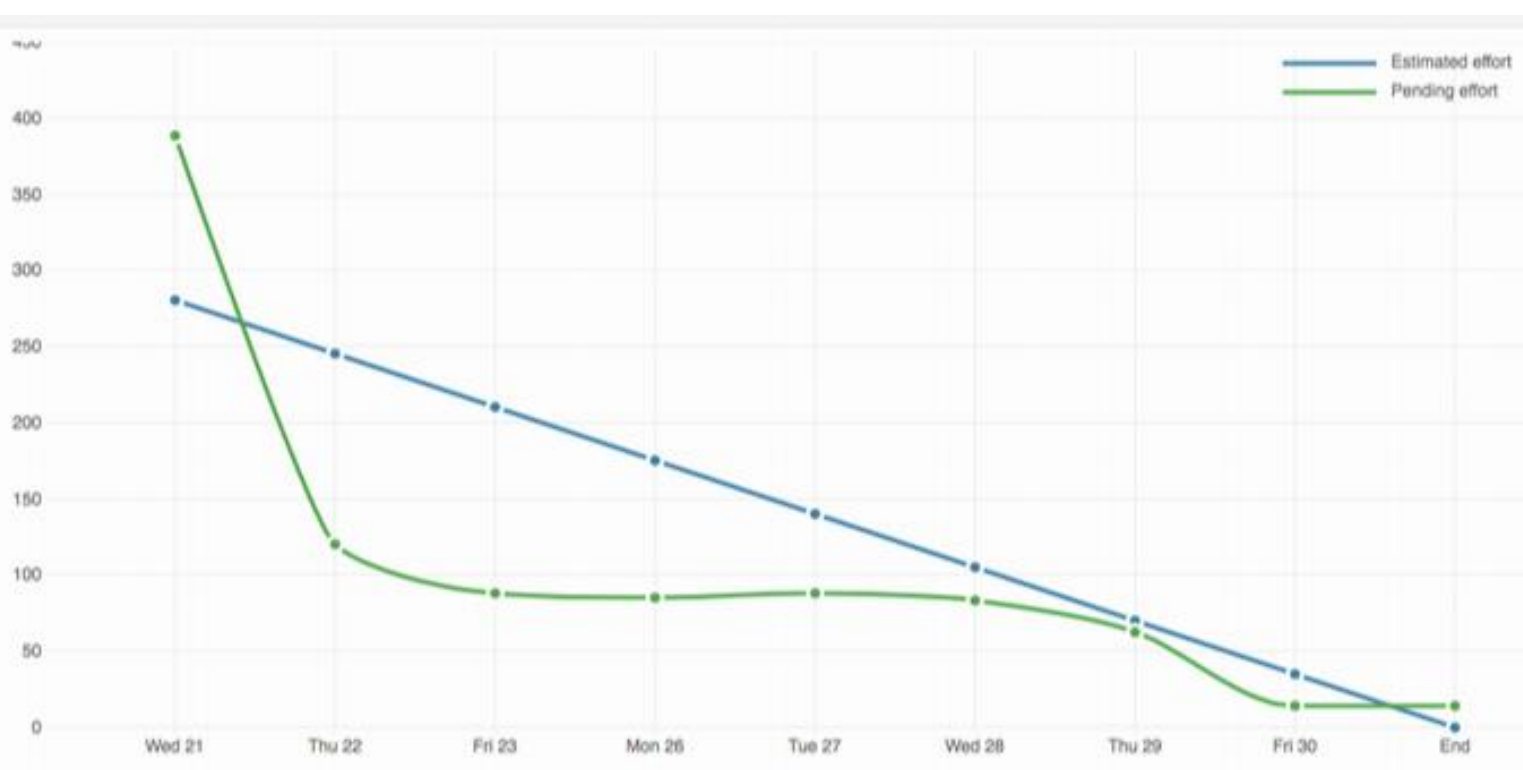

Fig. 6. Monitoring (Online Sprint Burndown Chart)

Burndown chart is a graphic that shows how much time it takes to complete the project. Burndown chart reflects the progress of the project. In Fig 6 there is a pending effort and the effort estimation, it can be seen that the average of the effort pending is below the estimated effort, which means the working progress is faster

\section{4) Sprint Review}

The people who do the task will demonstrate (running) the software feature that has been done, the demo is done by the whole team and presented without slides alternately every final sprint. Sometimes the client / customer wants to see how far is the progress of the software has been completed, therefore the product owner invited the client to come to the developer place and demonstrate the systems in front of them or through the online demo which is done at the client.

\section{5) Sprint Retrospective}

The Scrum Team discusses which task is encountering a problem, which task can be continued and that cannot be continued for the next sprint.

\section{B. Result}

Based on the discussion of the implementation process of the scrum method, then there some benefits that can be seen in Table 4.

TABLE V. BENEFITS IMPLEMENTATION OF SCRUM METHOD

\begin{tabular}{|c|c|}
\hline Case & Description \\
\hline Task Details Estimation & With the Scrum method, the details of the task has been clearly seen at the end of each sprint ( 2 weeks) \\
\hline Quality & $\begin{array}{l}\text { Sprint provides strength for team to undertake the development of software that has been determined in advance, so } \\
\text { that the quality of the software is in accordance with the business on the sprint. }\end{array}$ \\
\hline Quality Control & $\begin{array}{l}\text { In terms of quality control it can be evaluated at the end of a sprint, so the quality of the application is visible in the } \\
\text { final sprint. }\end{array}$ \\
\hline Risk & With the Monitoring Board and Online Monitoring Board showed that mistakes happen all the time. \\
\hline Application View & $\begin{array}{l}\text { At the end of the sprint, each team demonstrates the task that has been done, therefore at the end of the sprint the } \\
\text { display of the software being developed is visible. }\end{array}$ \\
\hline Business Change & Once the software is demonstrated, if there is any business changes, it will be directly discussed in the final sprint \\
\hline Customer Feedback & Customer sees the software demo and if there is any feedback it will be directly discussed in the final sprint \\
\hline Project Monitoring & $\begin{array}{l}\text { With the Monitoring Board and Online Monitoring Board, it provides an ease and the monitoring of the project can } \\
\text { be done at any time. }\end{array}$ \\
\hline Live (Production) & $\begin{array}{l}\text { Sprint in the Scrum provides convenience in live applications, where live can be done per product backlog that has } \\
\text { been made. }\end{array}$ \\
\hline
\end{tabular}




\section{CONCLUSIONS}

Based on the analysis that has been made and the results of the discussion in the previous section, then some conclusions can be drawn as follows:

- The quality and project risks seen more quickly.

- Business Change and Customer Feedback will be visible in the final sprint.

- Speed of visible projects in real time.

- Live Application can be done per product backlog.

In future studies a new method will be added to improve business change and customer feedback should be limited so that the project is not delayed.

\section{REFERENCES}

[1] Brunetti, G., et al, "Future business software : current trends in business software development".

[2] D'Costa, A. P., E. Sridharan. "India in the global software industry : innovation, firm strategies and development", New York, Palgrave Macmillan, 2004.

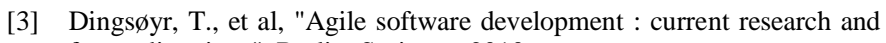
future directions", Berlin, Springer, 2010.

[4] Ebert, C., SpringerLink (Online service), "Best practices in software measurement how to use metrics to improve project and process performance", Berlin, Springer-Verlag,: xi, 295 p, 2005

[5] Falls, M. , Books24x7 Inc., "Inside the minds the software business : how top companies design, develop \& sell successful products \& applications", Inside the minds. Boston, Mass., Aspatore, 2004.
[6] Fort, T. L., "Prophets, profits, and peace : the positive role of business in promoting religious tolerance". New Haven, Yale University Press, 2008.

[7] Freeman, R. B. , K. Shaw, "International differences in the business practices and productivity of firms", Chicago ; London, University of Chicago Press, 2009.

[8] Fujita, H. , P. Johannesson, "New trends in software methodologies, tools and techniques : proceedings of Lyee W03, the second International Workshop on Lyee Methodology". Amsterdam ; Washington, DC, IOS Press, 2003.

[9] Langer, A. M., "Guide to software development designing and managing the life cycle". London ; New York, Springer,: 1 online resource (xvii, 350 p.), 2012.

[10] Martin, R. C., "Agile software development : principles, patterns, and practices",Upper Saddle River, N.J., Pearson Education, 2003

[11] Opelt, A. , Books $24 \times 7$ Inc., "Agile contracts creating and managing successful projects with Scrum". Wiley series in systems engineering and management. Hoboken, N.J., Wiley, 2013.

[12] Pfleeger, S. L., J. M. Atlee, "Software engineering : theory and practice". Upper Saddle River, NJ, Pearson Prentice Hall, 2006.

[13] Pham, A., et al., "Scrum in action Agile software project management and development". Boston, Mass., Course Technology PTR, 2011.

[14] Schniederjans, M. J., et al., "Information technology investment decision-making methodology". Singapore ; Hackensack, N.J., World Scientific, 2005.

[15] Stober, T. ,U. Hansmann, "Agile software development : best practices for large software development projects". Heidelberg Germany ; New York, Springer, 2010.

[16] Venkatesh, U., "Distributed agile : dh2a: the proven agile software development methodology for geographically dispersed teams". Westfield, NJ, Technics Publications, LLC, 2011.

[17] Woodward, E., et al., A practical guide to distributed Scrum. Upper Saddle River, NJ, IBM Press, 2010. 